\title{
Gap-Fillers for Wooden Artefacts Exposed Outdoors-A Review
}

\author{
Magdalena Broda ${ }^{1,2, * \mathbb{C}}$, Paulina Kryg ${ }^{3,4}$ and Graham Alan Ormondroyd ${ }^{2}(\mathbb{C}$ \\ 1 Department of Wood Science and Thermal Techniques, Faculty of Forestry and Wood Technology, \\ Poznań University of Life Sciences, 60637 Poznań, Poland \\ 2 BioComposites Centre, Bangor University, Deiniol Road, Bangor LL57 2UW, UK; \\ g.ormondroyd@bangor.ac.uk \\ 3 National Museum of Agriculture and Food Industry in Szreniawa, 62052 Szerniawa, Poland; \\ p.kryg@muzeum-szreniawa.pl \\ 4 Department of Wood Chemical Technology, Faculty of Forestry and Wood Technology, \\ Poznań University of Life Sciences, 60637 Poznań, Poland \\ * Correspondence: magdalena.broda@up.poznan.pl
}

check for updates

Citation: Broda, M.; Kryg, P.; Ormondroyd, G.A. Gap-Fillers for Wooden Artefacts Exposed Outdoors-A Review. Forests 2021, 12, 606. https://doi.org/10.3390/ f12050606

Academic Editor: Tripti Singh

Received: 13 April 2021

Accepted: 10 May 2021

Published: 12 May 2021

Publisher's Note: MDPI stays neutral with regard to jurisdictional claims in published maps and institutional affiliations.

Copyright: (c) 2021 by the authors. Licensee MDPI, Basel, Switzerland. This article is an open access article distributed under the terms and conditions of the Creative Commons Attribution (CC BY) license (https:/ / creativecommons.org/licenses/by/ $4.0 /)$.

\begin{abstract}
Conservation of wooden artefacts that are exposed outdoors, mainly in open-air museums, is a very complex and difficult issue that aims to preserve both the integrity and aesthetics of valuable objects. Unceasingly subjected to several factors, such as alternating weather conditions and the activities of microorganisms, algae, and insects, they undergo continuous changes and inevitable deterioration. Their biological and physical degradation often results in the formation of gaps and cracks in the wooden tissue, which creates a need not only for wood consolidation, but also for using specialist materials to fill the holes and prevent further degradation of an object. To ensure effective protection for a wooden artefact, a filling material must both protect the wood against further degradation and adapt to changes in wood dimensions in response to humidity variations. A variety of substances, both organic and inorganic, have been used for conservation and gap filling in historic wooden objects over the years. The filling compounds typically consist of two components, of which one is a filler, and the second a binder. In the case of inorganic fillers, plaster has been traditionally used, while the most popular organic fillers were wood powder, wood shavings, and powdered cork. As with binders, mainly natural substances have been used, such as animal glues or waxes. Nowadays, however, due to the lower biodegradability and better physicochemical properties, synthetic materials are gaining popularity. This article discusses the types of filling compounds currently used for gap filling in wooden artefacts exposed outdoors, outlining their advantages and drawbacks, as well as future perspective compounds. It appears that particularly composite materials based on natural polymers deserve attention as promising filling materials due to their high elasticity, as well as similarity and good adhesion to the wooden surface. Their main shortcomings, such as susceptibility to biodegradation, could be eliminated by using some modern, bio-friendly preservatives, providing effective protection for historic wooden artefacts.
\end{abstract}

Keywords: gap-fillers; gap-filling materials; wooden artefacts; wood conservation; wood exposed outdoors; microballoons; resins; glass beads; cellulose powder; binders

\section{Introduction}

Open-air museums (so-called skansens) play an indispensable role in the preservation and presentation of a threatened heritage of regional or national history. Giving us insights into the natural and cultural past of particular regions and the ethnic groups that were living there, these unique institutions help forge the sense of identity of the people in the area.

The idea for open-air museums in Europe came in the 18th century in Denmark as an evolution of traditional indoor type museums to preserve traditional village architecture in the rapidly developing world and thus maintain the cultural and historical consciousness of people. The first skansen was established in 1867 in Norway. Since that time, open-air 
museums began to develop - at first mainly in Scandinavia, and then throughout Europe and the world. Some of them were established to preserve historical buildings in the place of their origin or to save unique archaeological discoveries exactly in the area where they were made, while others were erected from scratch in new suitable places where the interesting objects were transferred to [1-3].

Open-air museums are often called "living museums" as they hold collections of intangible heritage resources, providing an interpretation of how people lived and acted in the past thanks to the achievements of experimental archaeology. They are a specific kind of medium linking culture and people, imparting values, knowledge and experiences of the past to subsequent generations. Their quest is to present historical treasures attractively and extensively, and help visitors appreciate and enjoy the rich heritage of the region. Although the significance of a museum does not rely only on its collection, but also on the philosophical, anthropological and cultural impact on society, the truth is that behind all these ideas are impermanent materials. In the case of open-air museums, the main collections are traditional buildings and structures exposed at large outdoor sites, and the primary material from which they came is usually degradable wood. Therefore, to fulfil their mission, the museums have to find a way to reconcile the intangible and the tangible, and save the wooden historic landmarks from decay, destruction, and ultimately the loss of the artefact [3-5].

The main wooden artefacts presented in open-air museums are various buildings, including cottages, huts, farm buildings, churches, wind- or watermills, as well as smaller structures, such as wayside shrines and crosses, beehives or statues (a few examples of wooden objects from the collections of The National Museum of Agriculture and Food Industry in Szreniawa and its branch-The Museum of Apiculture in Swarzędz, Poland are presented in Figures 1 and 2). Their outdoor exposition unceasingly subjects them to various abiotic and biotic factors that cause them damage.
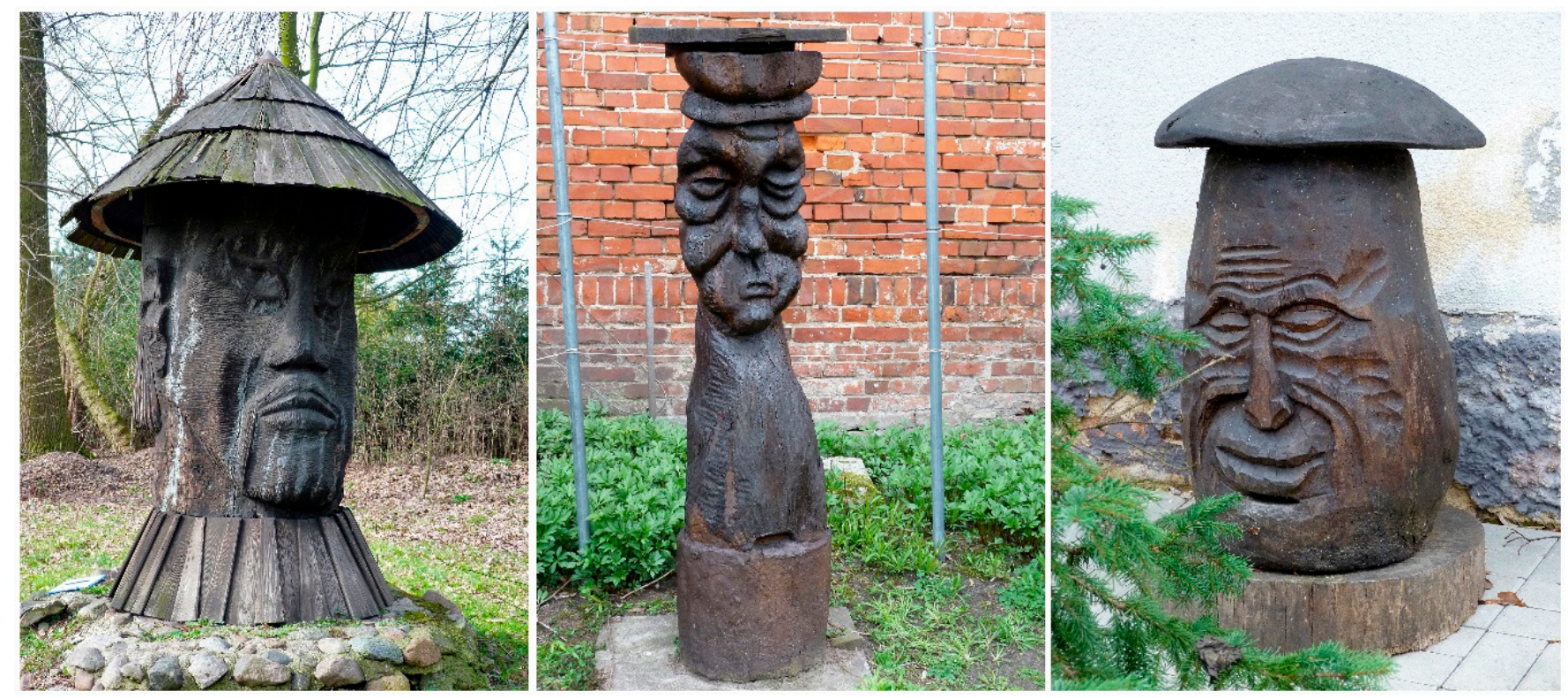

Figure 1. Three examples of wooden beehives from the collection of The Museum of Apiculture in Swarzędz, a branch of The National Museum of Agriculture and Food Industry in Szreniawa, Poland; from the left: a beehive No. MS E-128 called "Chinese", a beehive No. MS E-63 called “The Priest", a mushroom-shaped beehive No. MS E-242. 

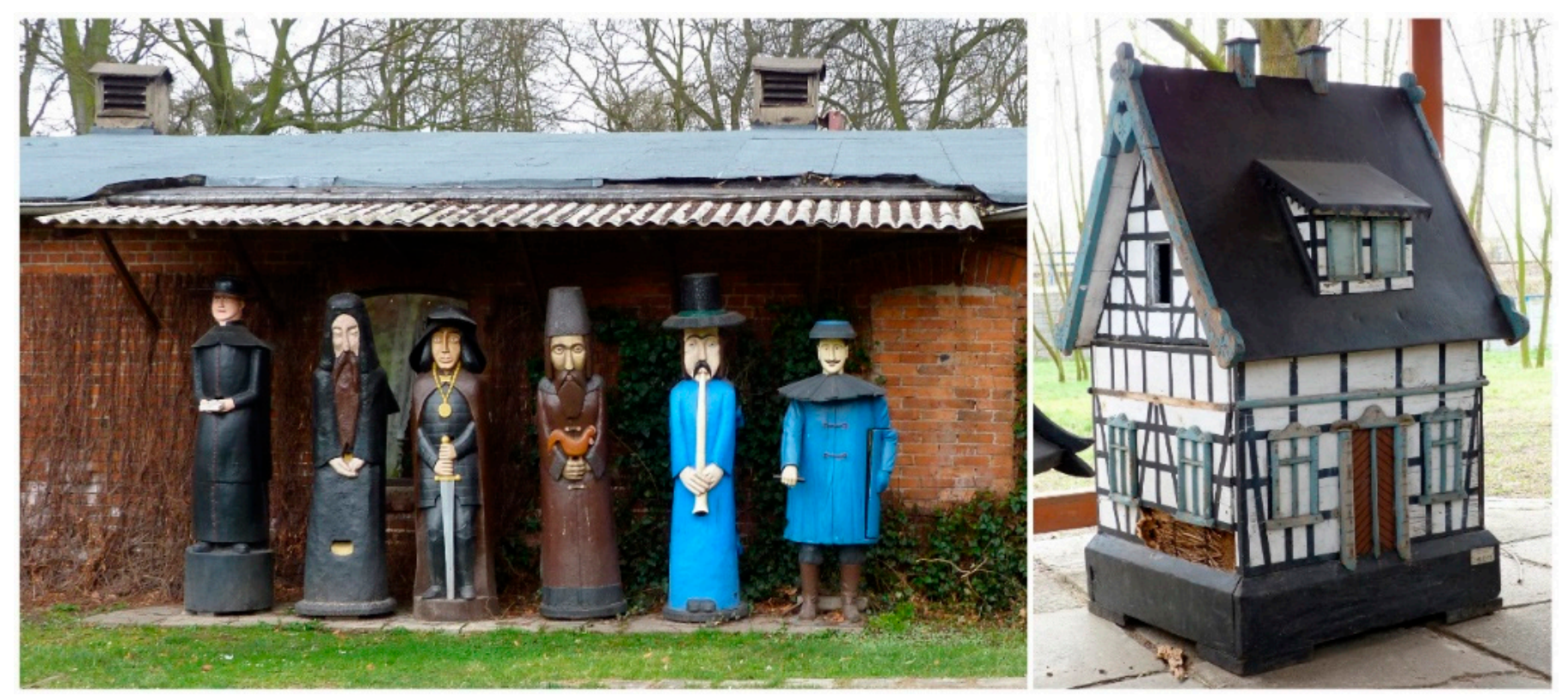

Figure 2. Wooden relics from the collection of The Museum of Apiculture in Swarzedz, a branch of The National Museum of Agriculture and Food Industry in Szreniawa, Poland; from the left: a set of figural beehives and an example of an architectural beehive (No. MS E-111).

The objects exhibited in the open air are constantly exposed to changing weather conditions. Precipitation and humidity variations result in alterations in wood dimensions, i.e., cyclic swelling and shrinking, which can cause wood deformation or even cracking (Figures 3A,D,E and 4D). Cracking and deformations impair an artefact's aesthetic, but the object that is cracked all over is also at risk of breaking apart into pieces and disintegrating. The rainfall and high air humidity, but also water that accumulates in cracks, promote further microbial, fungal, or algae infestation, which leads to the decay of wooden tissue and the creation of holes cavities (Figures $3 \mathrm{D}, \mathrm{E}$ and $4 \mathrm{~A}-\mathrm{C}$ ). UV radiation, temperature fluctuations or activity of wood-boring beetles and other insects that occur in the surrounding environment create further damage (Figure $3 \mathrm{~A}-\mathrm{C}$ ). As a result, the structural, mechanical, and chemical properties of wooden artefacts deteriorate over time, along with their aesthetic and artistic qualities. Such objects are usually full of cracks and hollows of various shapes and dimensions [6-9]. This creates a need for the application of not only typical wood conservation agents to consolidate wood and preserve the whole artefact, but also special materials to fill the gaps and keep the integrity and aesthetics of valuable objects and prevent their total destruction. Conservation of such types of historical objects is thus a challenging and complex issue requiring specific interdisciplinary knowledge and integrated technical and artistic conservation measures, which together ensure relevant results being concurrently in line with conservation ethics and excellence. 


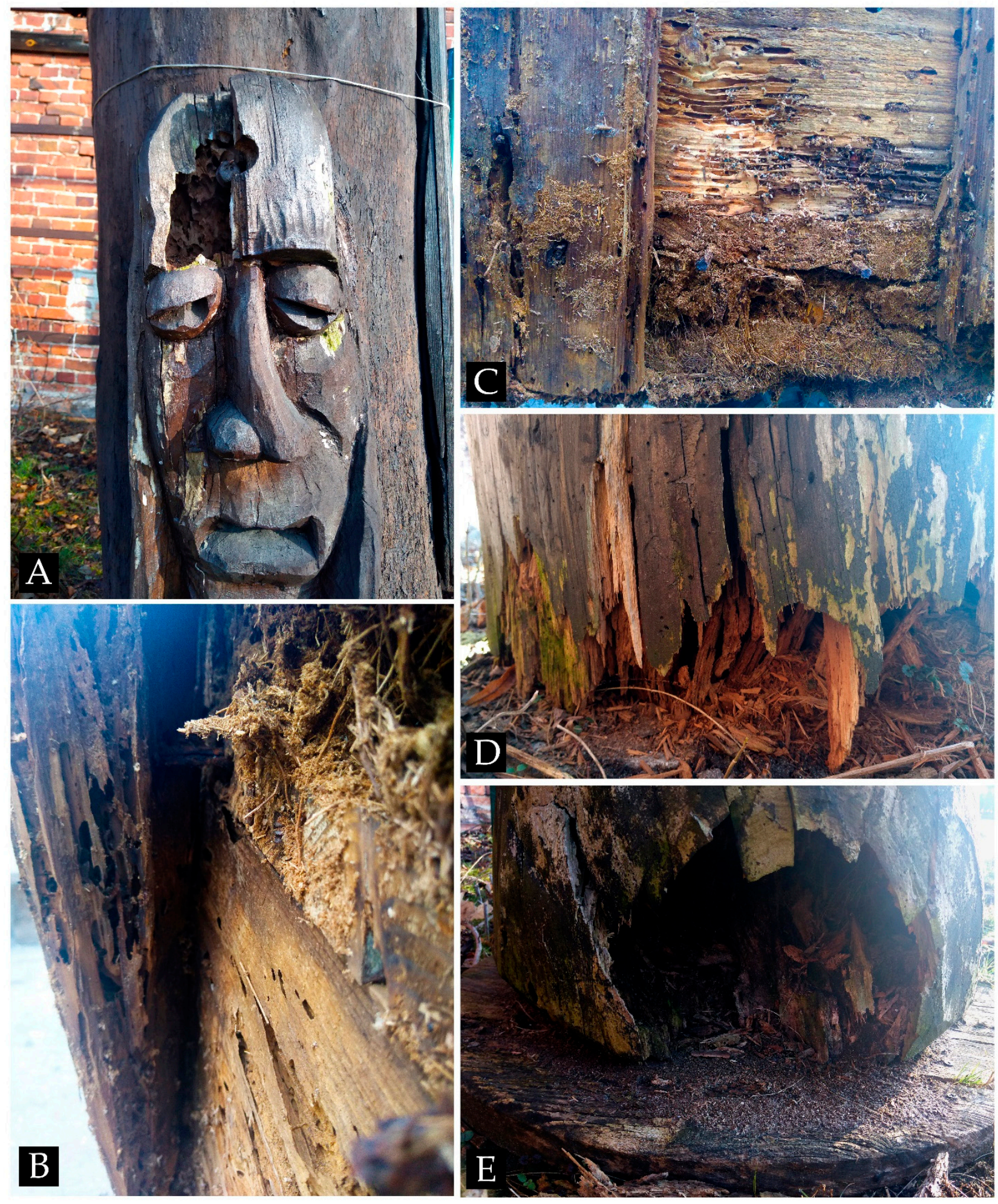

Figure 3. Damage on wooden objects exposed in the open air ((A-E): artefacts from the collection of The Museum of Apiculture in Swarzędz, a branch of The National Museum of Agriculture and Food Industry in Szreniawa, Poland). 

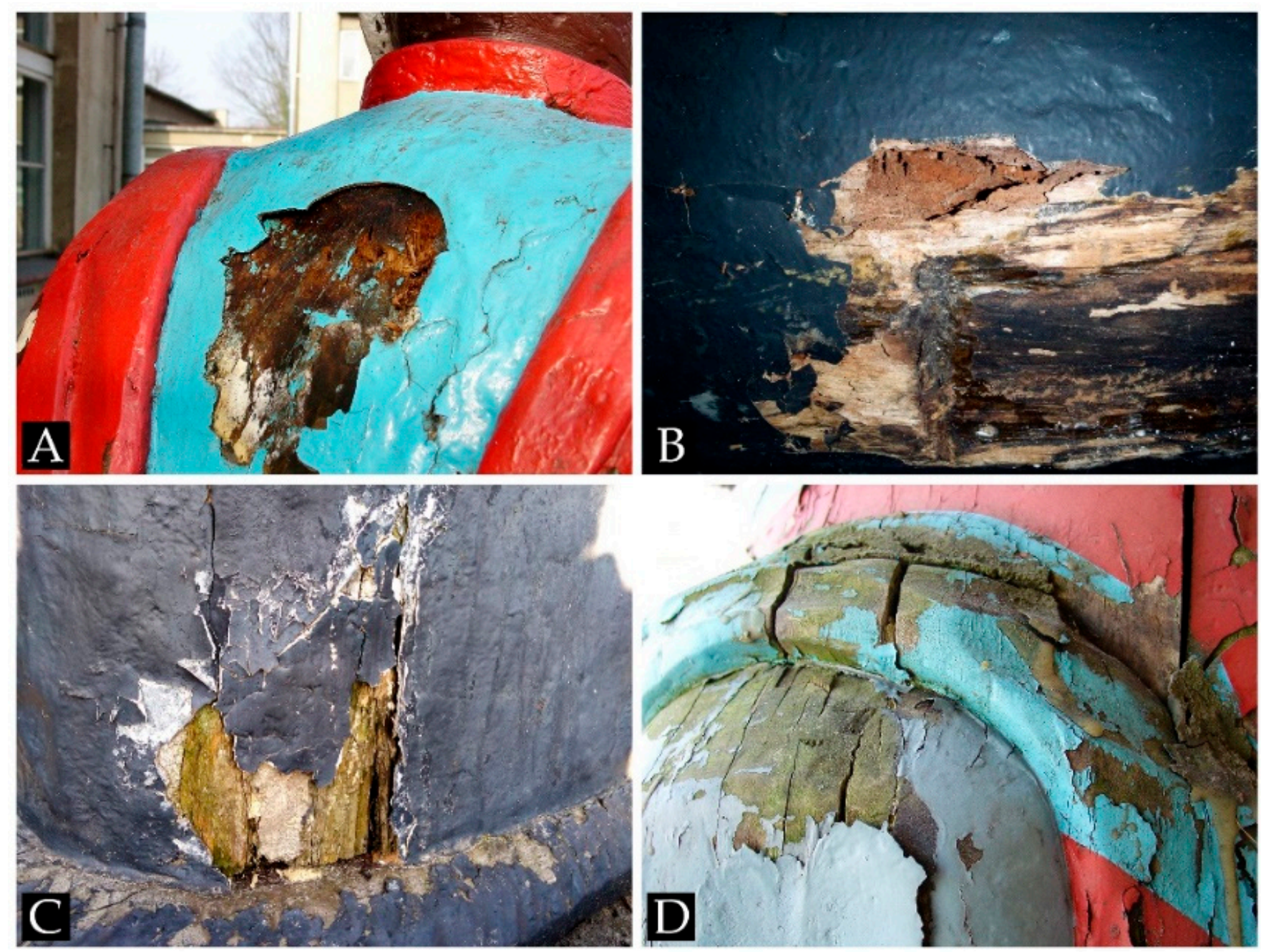

Figure 4. Damage of wooden objects covered with paints ((A-D): artefacts from the collection of The Museum of Apiculture in Swarzędz, a branch of The National Museum of Agriculture and Food Industry in Szreniawa, Poland).

This paper focuses specifically on the gap-filling of wooden artefacts exposed outdoorsan important but often overlooked problem in wood conservation. The article reviews the filling compounds currently applied for gap-filling and discusses their usefulness for wooden objects exhibited in the open air. It revolves around the features of filling materials that are the most required from the conservation perspective, outlines the advantages and drawbacks of these materials, and presents possible future perspectives in this field.

\section{Materials for Gap Filling in Wooden Objects}

Filling gaps in historical artefacts is in line with a philosophical trend based on the idea to conserve historical material rather than replace it. The reasons for gap-filling in wooden objects exposed outdoors are twofold, depending on the state of their preservation. Firstly, when the damage to an object threatens its existence (e.g., loss of stability (Figure 5B,C), deep cracks leading to splits and disintegration (Figure 5A,D)), then conservation considerations prevail, and a structural fill is necessary to provide an object with adequate strength and integrity. On the other hand, when multiple holes and cracks in an object cause the loss of its aesthetic quality and historical character that impedes the right interpretation of the artefact (Figure 6), aesthetic concerns predominate, and a soft, nonstructural fill is desirable $[10,11]$. Filling materials should then permit the degraded historical artefact to be "reconditioned and retained in place" [12]. 

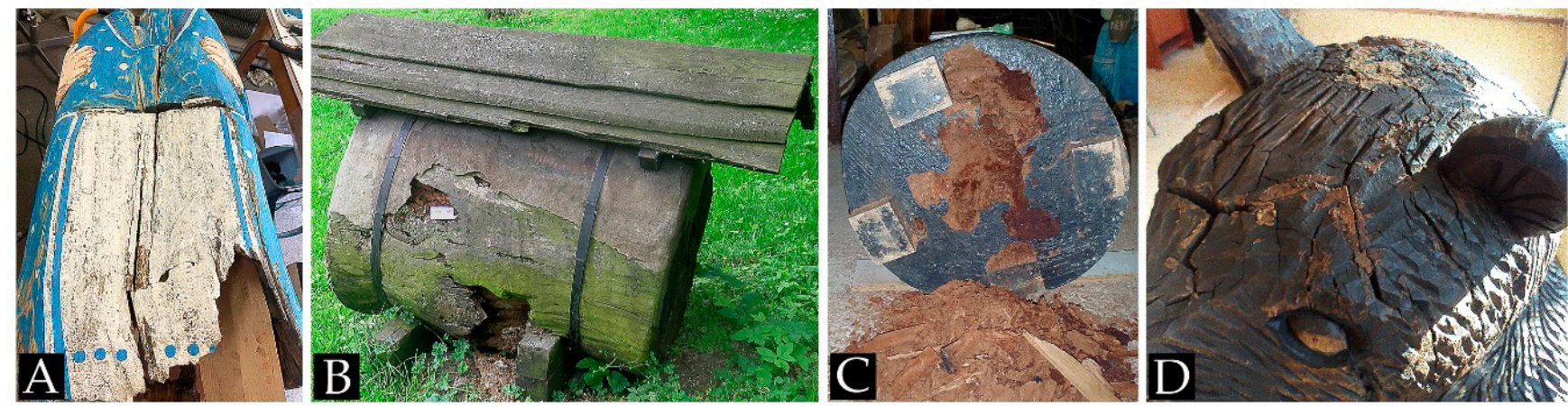

Figure 5. Structural damage of wooden objects that threatens their existence (artefacts from the collections of The Museum of Apiculture in Swarzędz (B,C), and The National Museum of Agriculture and Food Industry in Szreniawa, Poland (A,D)).
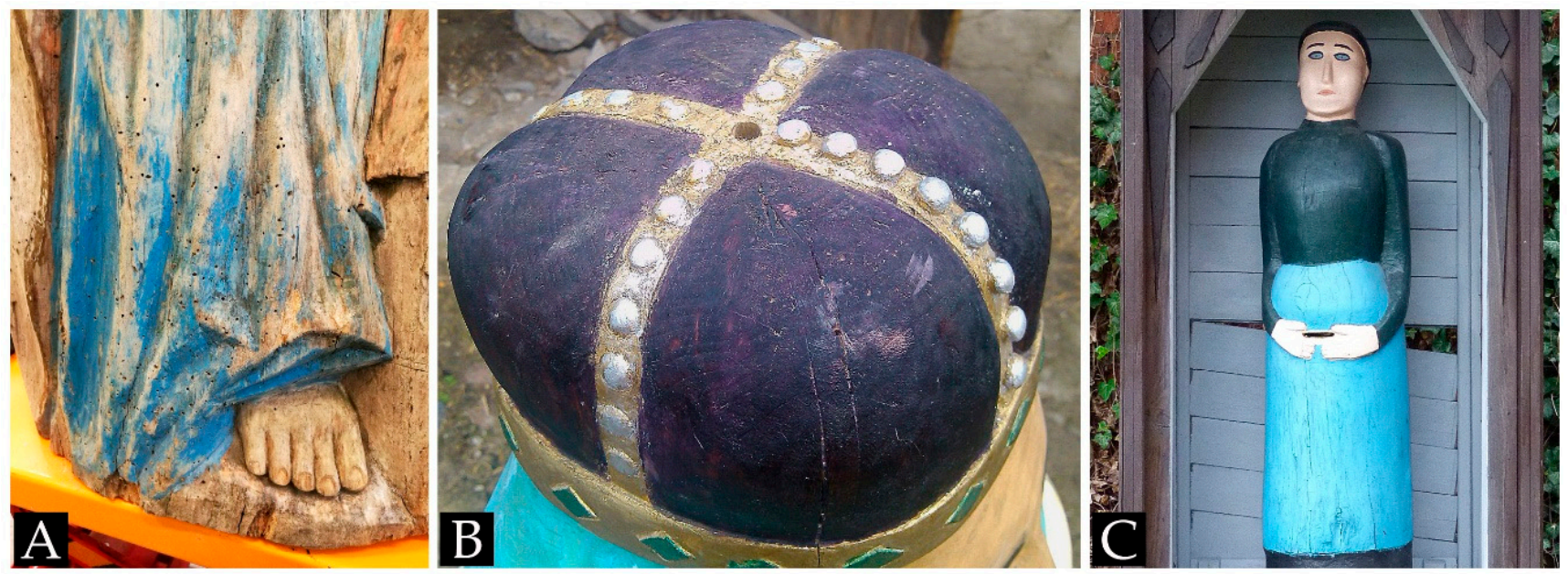

Figure 6. Damage that causes loss of the aesthetic quality of wooden objects (artefacts from the collection of The Museum of Apiculture in Swarzędz (C), and The National Museum of Agriculture and Food Industry in Szreniawa, Poland (A,B)).

A variety of materials have been used to fill gaps in wooden artworks exposed outdoors, including organic and inorganic compounds. Historically, mainly natural materials were applied, such as wooden fills, waxes, plaster, chalk, bitumen, concrete, gesso or oilbased putties. Then, due to their better performance, synthetic materials have become more popular; these include various resins (acrylic, epoxy, methacrylic, and vinyl), polyurethane, and silicone rubbers mixed with sawdust or synthetic microballoons [10,12-17]. Recently, as in other areas, a return to nature can be observed in wood conservation. This reflects the application of natural fillers, such as cellulosic materials (paper pulp, microcrystalline cellulose, long fibre tissues, cellulose or wood powder) or minerals (Halloysite nanotubes, silicates) in combination with natural biocides and various binders, including resins, natural oils, waxes, cellulose ethers, and other adhesives [18-27]. Conservators also use commercial ready-mixed compounds that include not only fillers and adhesives, but also additional agents, such as pigments, biocides, emulsifiers or thickeners (e.g., Plastic Wood, Polyfilla, AJK dough), or home-made pastes of confidential composition adjusted to the needs of individual wooden artefacts [13,28,29].

Conservation materials for filling holes and cracks in exterior wooden artworks face much more challenging conditions in comparison with museum interiors. Therefore, their properties should match the requirements imposed by the outdoor environment. Flexibility and cohesive strength proportionate to that of wood are two of the most important features due to the changing outdoor humidity and the resulting swelling and shrinkage of the wood. The ideal material would be one that could respond to these changes, i.e., expand when wood shrinks and shrink when the wood swells. It should adhere well to the void's surface and provide proper fusion with wood tissue. Fillers also need to be resistant to 
weathering (ageing) and leaching. Their physico-chemical and mechanical properties should correspond with wood to avoid its damage. Filling materials ought to be removable (conservation ethics require the method to be reversible or at least enabling retreatability), easy to prepare, apply and work, as well as to carve or paint, non-toxic, preferably also easily accessible, and relatively inexpensive [11,18,30-32]. The key to providing proper conservation of a wooden artefact is an individual approach to each case that involves thorough characteristics of an object and its state of preservation, as well as choosing the most appropriate conservation materials and methods tailored to the artefact and that correspond to both aesthetic and conservation requirements $[13,17,18]$.

Fill compounds are two-part systems that consist of a cohesive material (filler) to replace the loss in the wood structure and an adhesive (binder) to affix the material in a conserved object. These two constituents can be separate, as in the case of a properly shaped wooden fill glued into the void using an adhesive, or mixed together into a single filling mass that ensures both filling the loss and adhesion to its surface [10]. Masses are then multi-component mixtures of adhesive(s) and bulking agent(s) blended in the right proportions to provide requested physical and mechanical properties. They can be simple mixtures of chemically inert agents or a blend of compounds that can chemically react with each other or crystallise to form a final filling material with appropriate characteristics. However, in conservation practice, there are also more complex recipes with various interactions between their components [17].

\subsection{Fillers (Bulking Agents)}

The primary function of a filler is to replace the missing wooden tissue and fill cavities in an artefact. However, as mentioned above, fillers are usually mixed with adhesives to form a homogeneous ready-to-use filling paste. In such a case, they serve also other functions, such as:

- increasing the viscosity of an adhesive to obtain a stiffer paste, which facilitates its application and prevents its draining from holes or cracks during the conservation process,

- enabling the filling mass to be carved or sanded to facilitate its further painting or to make its surface similar to the surface of the surrounding wood,

- reducing shrinkage of a filling mass when an adhesive used contains volatile components,

- modifying the mechanical properties of an adhesive, thus the whole filling mass, depending on the filler/adhesive ratio,

- altering the volume of the mass in response to changing moisture conditions, depending on the hygroscopicity of a filler $[11,18,33]$.

Several different bulking agents have been used in gap-filling of wooden artefacts exposed outdoors, including both natural (organic and inorganic) as well as synthetic compounds: wooden fills, wood flour, sawdust, wood shavings, coconut fibres, cork granules, rye flour, cellulose powder, lignin, gypsum, chalk, mineral powders, metal or glass powders, glass beads, glass or phenolic microballoons, synthetic fibres, synthetic polymers (powdered or granulated) $[13,18,23,31,33,34]$.

\subsubsection{Wooden Fills}

One of the solutions applied for filling gaps in wooden artefacts are fills made of wood that can serve as structural or aesthetic compensation. Seasoned wood, usually of the same species of which the wooden object is made, is carved to an appropriate shape for a tight fit. Then it is mounted in the cavity using an adhesive, and its surface is matched to the surrounding area of an artefact [10].

Although this historically oldest conservation method seems evident and fully adequate, it has several drawbacks. The main problem is a different response of new and historic wood to external conditions, in particular to humidity fluctuations. Degraded historic wood is usually to some extent deprived of highly hygroscopic cellulose and hemicelluloses. Therefore, it is less reactive to moisture, thus less dimensionally responsive to it. When humidity changes, different wood pieces (old and new) contract or expand 
independently. More reactive fill made of fresh wood can detach itself from the artefact when it dries under low humidity conditions, creating new crevices leading to further damage of an object. When humidity rises, fresh fill expands, which can enlarge the existing gaps and cracks, and even completely destroy an artefact by splitting it into pieces. To avoid such scenarios, conservators sometimes use fills made of the same type of wood with a similar degree of degradation-historical wood with comparable age or fresh timber after artificial weathering $[10,11,13,32]$.

Other problems with wooden fills relate to their fitting to the cavities in a wooden object and visual matching to its surface. The former is difficult due to the usual irregularities of the voids: no matter how accurately carved and fitted, a filler will always eventually come adrift. The latter is complicated due to the individual grain pattern of each wood piece (grain orientation, the width of annual rings, colour). Considering all the above-mentioned facts, using fills made of wood seems not to be a perfect solution $[10,11,13]$.

\subsubsection{Sawdust, Wood Shavings, etc.}

Probably the most obvious and popular concept for gap-filling in historic wooden artworks is the utilisation of the same material they are made from due to comparable physico-chemical properties. Except for wooden fills described in the previous paragraph, wood or bark (cork) comminuted to a varying degree is often used in combination with different adhesives (mainly nonaqueous due to high swelling and shrinkage of fragmented wood in aqueous binders). Sawdust, wood shavings, and wood flour are cheap and easily available and thus are commonly found in recipes for moldable filling masses. They increase viscosity as well as enhance the hardness and tensile strength of these conservation materials, facilitating their application and further cutting and curving to an appropriate shape and texture. The size of wood particles is selected depending on the type and size of holes in an artefact $[16,17,32]$.

\subsubsection{Cellulose}

Various forms of cellulose (nanocellulose fibres and crystals, microcrystalline cellulose, paper pulp) and its derivatives (ethers and esters) have been used in the conservation of wooden artworks for consolidation and coating. For gap-filling, mainly microcrystalline cellulose (MCC) and paper pulp are applied as fillers in combination with different adhesives [21,31,35-37].

Microcrystalline cellulose is a natural, non-toxic, fully biodegradable, and recyclable material industrially manufactured from lignocellulosic biomass, usually agricultural, forest and aquatic residues (e.g., rose stem, sugarcane bagasse, rice and coffee husk, date seeds, brown algae, wood, bamboo fibre, tea waste). Its production involves partial hydrolysis of amorphous regions of native cellulose using strong mineral acids at boiling temperature. As a result, small particles (about $50 \mu \mathrm{m}$ in dimension and 100-1000 $\mu \mathrm{m}$ in length) of high crystallinity are obtained [38-41].

The high degree of crystallinity renders MCC a perfect reinforcing filler, providing it with high thermochemical stability and resistance to swelling in water combined with low density, high specific strength, and viscosity. Additionally, the widespread availability, the chemical composition identical to that found in wood, and the ease of handling make MCC a frequent conservators' choice for consolidation and gap-filling in wooden objects [18,20-22,36,42].

Results of the research by Cataldi et al. [20,22] on MCC/acrylate composite showed that MCC added as a filler to the commercial acrylate adhesive (Paraloid B72 (Dow Chemical Company, Midland, MI, USA) commonly used in wood conservation), significantly improved its thermo-mechanical behaviour by increasing its glass transition temperature and thermal degradation stability, and reduced linear coefficient of thermal expansion. Simultaneously, the addition of MCC increased the composite's stiffness, resistance to fracture propagation, stress at break, tensile energy to break and creep stability, as well as storage modulus and loss modulus proportionally to the rising filler/binder ratio. The stabilising effect of microcrystalline cellulose resulted from the properties of MCC itself 
and from a good filler/binder affinity. When applied as a consolidant for degraded wood, the composite additionally reinforced its structure by reducing the pore radius to the size of the corresponding sound wood and enhanced its mechanical properties (e.g., stiffness, flexure strength, and surface hardness); concurrently, it retained the hydrophobicity of the adhesive, reducing the wood moisture content and volumetric swelling of the treated wood [21]. An MCC/acrylate composite can be then particularly useful as a gap-filler for conservation purposes, " ... where elevated dimensional stability and a good energy absorption capability under external loads are required ..." ", as in the case of many wooden objects exposed outdoors [22].

Among cellulosic materials, paper pulp, sheet paper, newspapers or tissue paper have sometimes been used as fillers and have been combined with various, mainly natural adhesives. Due to the higher amount of amorphous regions in cellulose microfibrils, they are more hygroscopic than MCC, thus more prone to swelling when exposed to moisture [17,18,43]. Fulcher [18], however, showed that paper pulp in combination with Klucel ${ }^{\circledR}$ (hydroxypropyl cellulose) as an adhesive makes a great gap-filler that is compatible with wood and fits almost all the conservators' criteria. By changing the filler/binder ratio, we can change the properties of the mass and adjust it to the needs of a particular artefact.

There is a lot of new research on the use of cellulose derivatives as fillers for various composites, e.g., lignin-containing cellulose nanofibrils in combination with polymeric diphenylmethane diisocyanate as a wood adhesive [44], polypropylene/poplar wood flour/microcrystalline cellulose /starch powder or MCC/polyester composites with improved mechanical properties $[45,46]$, etc. The properties of the obtained composites are promising, and some of them can potentially be useful in gap-filling in wooden historical objects.

\subsubsection{Plaster and Cement}

Plaster has been used in conservation practice since antiquity. The name "plaster" can refer to two different types of calcium compounds: lime plaster made of calcium carbonate $\left(\mathrm{CaCO}_{3}\right)$ and gypsum plaster (so-called "plaster of paris") made of calcium sulfate $\left(\mathrm{CaSO}_{4}\right)$. Both are mixed with water (and other ingredients) to prepare a filling putty, but the former shrinks upon drying, while the latter, unlike other materials of this type, expands upon setting. Neither of them applied alone is fully appropriate for the conservation of wooden objects: lime plaster can shrink and crack during drying, sticking out from the hole's surface thus creating new gaps; gypsum plaster, by expanding upon drying, can destroy the surrounding wooden tissue leading to the destruction of a whole object [17]. However, in more modern times, plaster has been often used as a bulking component in various conservation masses for gap-filling: hard-finish plasters based on over-heated gypsum and metal salts with longer setting time (e.g., Mack's cement, Keating's, Keene's cement, Parian, Martin's cement); Portland cement made of calcium carbonate and alumino-silicates (more appropriate for large fills); gesso based on calcium sulfate or carbonate mixed with animal glue as the adhesive (unstable under changeable humidity conditions); composition (so-called "compo") made of animal glue, linseed oil, and a natural resin mixed with a calcium filler. They have been applied to various outdoor artefacts, including metal, stone, and wooden sculptures and structures, often in combination with different substances according to the needs of the individual pieces of art, but most of them are not suitable for degraded wood and under changeable moisture conditions [17,31].

\subsubsection{Microballoons}

Microballoons are miniature, non-porous, non-toxic, hollow, and perfectly spherical particles with a very low density and specific surface. They are available in the form of white, free-flowing powder, in a wide range of densities and respective compressive strengths. For art conservation, mainly glass, acrylic and phenolic microballoons have been used, often in combination with thermoplastic and thermosetting resins to provide them with better performance $[10,11,13,23,47]$. 
Microballoons are inert compounds easily mixed with resins without using complicated tools and procedures. They decrease the viscosity of the resin-filler mixtures without altering their weight and enable them to form thick, lightweight, and easy workable pastes suitable for various conservation purposes. Depending on the adhesive used, some of the masses can be reversible. Microballoons reduce shrinkage during drying and improve the smoothness of filling masses. They enable them to obtain the texture similar to surrounding wood and facilitate their carving and painting (especially the phenolic ones). They also minimise absorption of the resins used by the porous wood tissue, as well as prevent them from affecting water-sensitive painted surfaces or gesso present in conserved artefacts $[10,11,13,18,47-50]$. The addition of microballoons affects the compressive, flexural or tensile properties of resins; it has been shown that the increased volume fraction of microballoons increases Young's modulus, compressive strength, and impact resistance of such mixtures. Microballoons-based masses turned out to be effective for applications where dimensional changes upon changeable moisture conditions are minimal due to the high degree of wood degradation, but also, due to their low compressibility, for filling cracks in more reactive less degraded wood [29,47,50-52].

\subsection{Adhesives (Binders)}

Since adhesives applied for filling gaps in wooden artefacts exposed outdoors have to withstand changeable external conditions, their properties have to satisfy specific requirements. First of all, they should be flexible due to the high dimensional changes of wood caused by humidity fluctuations; their hardness and mechanical strength should be adjusted to the condition of the conserved artefact (the bond between wood and adhesive should be weaker than the wood cohesive strength to ensure the potential damage take place within the adhesive, rather than in the structure of the artefact). Binders cannot stain the surface or change the colour of the artefact and need to be resistant to weathering (ageing) and biodegradation. They cannot affect the wood structure, should be non-toxic, safe to handle, easily available, and cheap. To comply with conservation ethics, adhesives should also be reversible or, at least, retreatable [12,16,31,53].

Adhesives are usually mixed with fillers and excipients to form filling masses (pastes) adjusted to the requirements of specific objects, but some of them, especially synthetic resins, are sometimes used separately. In the past, mainly natural adhesives have been used, such as animal glues, natural oils or waxes. They have been replaced by synthetic polymers (e.g., acrylic, epoxy or vinyl resins, silicones, polyurethanes) with better performance and improved durability. There are also commercial adhesive formulations on the market, with properties suitable for outdoor applications, but still little is known about their endurance, resistance to ageing or reversibility $[11,13,16,31,33]$.

\subsubsection{Animal Glues}

Animal glues were among the first adhesives used in construction, manufacture, and conservation (their history dates back at least to ancient Egypt) and they are still in use to present times. Derived mainly from animal collagen — the most abundant mammalian protein present in bones, tendon, skin, connective tissue, and cartilage- they have different chemical, physical, and mechanical properties depending on their origin and a method of preparation. Nevertheless, they have proven to be extremely useful as adhesives and binding media for various purposes, and under certain conditions, they can be highly durable as evidenced by centuries-old fills or joints found in historical artefacts [17,30,54,55].

Animal glues are natural and water-soluble, which reflects in their properties. They are non-toxic, thermoplastic, as well as reversible and retreatable (unlike synthetic resins) and have great adhesion to the wood surface, which suits the conservation purposes. On the other hand, as a good source of nutrients, they are prone to biodegradation, and their hygroscopicity makes them susceptible to moisture changes, which results in their shrinkage, brittleness, and a tendency to fracture when they dry, or in their softening and bleeding when they undergo plastic deformation under wet conditions. These drawbacks 
predispose animal glues to serve mainly as interior adhesives [30,33,55-58]. However, their modification with additives such as inert fillers, plasticisers or pigments can significantly improve their performance (by limiting their dimensional changes upon moisture fluctuations and altering their mechanical properties) and give them the properties necessary for gap fillers for specific outdoor conservation purposes [57]. Animal glues do not stain the wooden surface nor cause wood discolouration and can be easily removed from places where they are undesired. Under optimal external conditions (without significant changes in moisture and temperature and limited risk of biodegradation), they can be stable and durable $[30,33,55]$.

Besides the glues based on mammalian collagen, there is a variety of different animal glues, including casein glue, albumin glue or fish glue, which have been applied as paint media, adhesives for architectural, manufactural, and conservation purposes, as well as binding media for bole and gesso in gilding $[33,55,59]$.

\subsubsection{Waxes, Oils, and Natural Resins}

Waxes are some of the oldest materials used in monuments craft and conservationbeeswax was used by ancient Egyptian craftsmen or applied by the ancient Romans to fix Greek marble statues damaged during transportation [60]. Apart from beeswax, other natural waxes have been used since the beginning of the 19th century, including those of plant (e.g., carnauba, candelilla, esparto, ouricuri) or animal origin (Chinese insect wax, lanolin, shellac wax, spermaceti); nowadays, mineral waxes originated from natural deposits (ozokerite or montan wax) or extracted from crude oil are also in use in the form of paraffin (larger crystalline size) or microcrystalline wax (smaller crystalline size) [17,61].

Waxes are used as coatings, binders or consolidation agents for degraded wood and can be suitable as gap fillers for wooden objects which are not subjected to high temperatures (close to or exceeding the melting point of waxes) $[17,31,55,60]$. They are non-toxic, inert, chemically stable, resistant to organic solvents, and hydrophobic. They are the traditional choice in conservation since they do not shrink upon setting, can be colour matched to the surrounding surface, and easily removed (due to their low bonding strength and lack of tension between the fill and the surrounding wood). On the other hand, the hydrophobic nature prevents them from expanding or contracting along with wood movements caused by humidity fluctuations, which can lead to falling out of wax fills. Unfortunately, waxes melt and leak out under higher temperatures and significantly increase the weight of a conserved artefact; they are prone to dust accumulation and can be easily scratched because they have poor mechanical resistance. However, their filling performance can be improved when they are mixed with fillers and adhesives $[17,55,56,62,63]$.

Linseed oil (so-called flax oil or flaxseed oil) has also been widely used in wood craft and conservation. It is non-toxic and water-resistant, ubiquitous, easily available and relatively cheap, and as a drying oil that can polymerise into a solid form when exposed to oxygen from the air, it is perfect for various purposes: for finishing wood surfaces, for wood impregnation when blended with resins, other oils or solvents, as a plasticiser and hardener in putties and other filling masses, or as a pigment binder in paints and gildings. However, the development of synthetic resins with better performance significantly limited its application in the past few decades [55,56,62].

Natural tree resins were also utilised in the past for art craft and conservation. Although relatively thermo-chemically stable, they have insufficient flexibility and adhesion to wood to serve as components of gap-fillers in wooden objects [31].

\subsubsection{Cellulose Ethers and Esters}

Cellulose, as mentioned above, can serve as a filler, but its soluble derivatives-ethers and esters-are also used as adhesives or consolidants in wood conservation. 
Cellulose ethers are water-soluble polymers produced by chemical modification of cellulose. The modification process includes extraction of cellulose from natural fibres (cotton, wood), treatment with an alkaline solution, and then reaction with various etherification reagents. The process disrupts hydrogen bonds in cellulose, which allows other compounds to bond with glucose units, but also results in a significant reduction of cellulose crystallinity. The resulting products are hygroscopic white powders applied as thickeners, stabilisers, and viscosity modifiers in a variety of industries, and their properties are similar to some synthetic or natural water-soluble polymers (polyurethanes, polyacrylates, polyvinyl alcohol or carrageenan, xanthan gum, locust bean gum) $[18,58,64,65]$.

In wood conservation, mainly methyl and hydroxypropyl cellulose are used as consolidation agents or adhesives; however, other ethers have been recently tested $[18,23,24,36,55,66,67]$. The most common compound is Klucel ${ }^{\circledR}$ (hydroxypropyl cellulose), available in a wide range of grades and viscosity; however, because high-molecular-weight Klucel ${ }^{\circledR}$ (types H and M) was found unstable, mainly the low molecular G type is in use. Klucel ${ }^{\circledR}$ is soluble in water or ethanol; it has been applied as an adhesive in combination with paper pulp, microballoons, and cellulose powder, or a mixture thereof, for filling loses in wooden objects exposed mainly in museum interiors $[18,68-70]$. It was shown to be susceptible to ageing/weathering, similar to cellulose or other cellulose ethers [18].

Studies on Klucel ${ }^{\circledR} \mathrm{G}$ mixed with ground chalk revealed that such a mass is prone to slump and shrink upon drying; therefore, is not suitable as a gap-filler [13]. On the other hand, as shown by Fulcher [18], a blend of Klucel ${ }^{\circledR} \mathrm{G}$ with paper pulp meets almost all the criteria set for gap fillers for wooden artefacts. The fill is compatible with wood and responds to moisture fluctuations similarly to wood. Therefore, potentially, it could be used outdoors. Its hardness and strength can be adjusted to the requirements of the object by changing the concentration of an adhesive, and it can be prepared using a variety of solvents suitable for individual artefacts. The important thing is that the fill should be considered a system, and its properties are not a sum of the properties of its components because individual ingredients-a bulking agent, an adhesive, and a solventaffect each other, modifying the resulting material and its reactions to the surrounding environment. Kryg et al. [23] studied fills composed of Klucel ${ }^{\circledR} \mathrm{G}$ and wood powder or glass microballoons as bulking agents, using acetone or water as solvents. The results show that the properties of the examined fills differed significantly depending on the solvent and the filler/adhesive ratio. Because all the fills were susceptible to water, none of them was suitable for external application.

Among other cellulose derivatives sometimes used in conservation are cellulose esters: nitrate and acetate. They dry quickly and degrade easily by discolouring and releasing acidic vapours, become brittle in time and prone to cracks, and their binding properties are relatively weak. To improve its filling performance, cellulose nitrate was sometimes plasticised with other materials; mixed with wood dust served as a filling mass called "Plastic Wood". Today, however, there are plenty of better adhesives. Therefore, cellulose esters are not a primary choice as adhesives for wood conservation $[17,56,58]$.

\subsubsection{Synthetic Resins}

Synthetic resins are liquid, semi-liquid or soft solid viscous substances industrially produced in polymerisation, polycondensation or polyaddition reactions. They are mixtures of prepolymers (oligomers and short polymers) that contain highly reactive functional groups, which enable their further polymerisation and cross-linking in the process called curing. It leads to the formation of rigid polymers as final products. Depending on the chemical structure and the production method, there are various classes of synthetic resins, including acrylic, epoxy, vinyl, polyurethane, etc. Considering their reversibility, there are two different types of resins: thermoplastic, which softens upon heating and hardens again-they are easily moulded, and therefore are suitable for filling purposes-and thermosetting, which undergo irreversible hardening by curing. Synthetic resins are applied widely as adhesives, coatings, cross-linkers, etc. They are also used in art conservation as 
consolidants, adhesives or protectives and are considered as more resistant to degradation and better performing compared to natural adhesives [30,31,53,58,71]. Some of the most common synthetic resins in wood conservation are described below.

- Acrylic resins

Acrylic resins are thermoplastic or thermosetting polymers commonly used in artwork conservation. They are colourless, transparent, inert, reversible, insoluble in water, but easily soluble in organic solvents including fast-drying acetone or safe for finishes or paints xylene, which are frequently used in wooden artwork conservation. They have good adhesion and mechanical properties. Although highly resistant to temperature, acids and alkalis, in the long term they are prone to microbial degradation, UV radiation, and mechanical damage to some extent, which can change their physical and mechanical characteristics $[20,22,30,61,72,73]$.

Paraloid B72 (methyl-acrylate/ethylene methyl-acrylate copolymer) is the most popular acrylic resin applied in conservation and restoration owing to its flexibility, good optical properties, and removability combined with higher photo-thermal oxidation stability and lower water sorption than other members of this resin family. It performs well as a consolidant for degraded wood, a barrier coating or protective layer for different surfaces, but is also useful as an adhesive, including its application for gap-filling masses in combination with different bulking agents [20-22,31,72,74]. When mixed with microcrystalline cellulose, it can form an innovative thermoplastic composite with enhanced thermal stability and mechanical performance (including an increase of the elastic modulus and storage modulus, as well as improved creep stability) proportional to the concentration of MCC. Although MCC increased the moisture content of the composite, it also had a stabilising effect on it. The results show that the addition of MCC is an efficient way to improve the performance of acrylic resins used for conservation purposes where dimensional stability and energy absorption capability under external loads are necessary, which relates to some of the requirements for gap-fillers for wooden artefacts exposed outdoors [20,22]. A study by Kryg et al. [23] revealed that a blend of higher concentrations of Paraloid B72 and glass microballoons, although not highly flexible, was relatively dimensionally stable upon drying and exposure to water vapour and liquid water (despite high absorption of moisture) and was quite easy to finish; these features make it potentially useful as a gap-filler for external use. On the other hand, the blends of Paraloid B72 and wood powder turned out to be soft and fragile, difficult in finishing, and highly sensitive to moisture. Only those with a binder concentration of $50 \%$ were relatively compact and stable under humid conditions [23].

There is also a variety of commercial fillers based on acrylic polymers that are potentially useful in filling losses in wooden objects. These ready-to-use fillers contain various binders, bulking agents, and additional substances. The problem is that their composition is a trade secret; therefore, it is hard to predict their properties under certain conditions. Although they are usually recommended by manufacturers for particular applications, there are limited references for their use in wood conservation [15].

- $\quad$ Epoxy resins

Epoxy resins are reactive polymers or pre-polymers that contain epoxy groups. They are soluble in organic solvents, and their solubility depends on their molar mass. Lowmolecular-weight liquid resins are soluble in toluene, xylene, benzene, acetone, cyclohexanone, etc. Higher-molecular-weight solid-state resins are soluble in acetone and cyclohexanone, and partially soluble in aromatic hydrocarbons. Due to reactive epoxy groups, epoxy resins can cross-link with themselves or with several different chemicals (e.g., acids, alcohols, amines, phenols, thiols, etc.) in the process called curing or hardening, forming a thermosetting polymer as a final product. Epoxy polymers are insoluble, relatively resistant to weathering, moisture, and UV radiation, with enhanced mechanical properties and thermo-chemical resistance. Therefore, they are employed widely in different industries, i.e., as adhesives, coatings, and components of composite materials [61,75]. 
Epoxy resins are also useful in wood conservation and applied as adhesives (e.g., for conservation of panel paintings), consolidants or fillers. Different formulations can make them compatible with concrete, glass, stone, wood, or other materials. Since they are thermosetting polymers, they should be considered irreversible, which is against conservation rules. Nevertheless, in some cases, where the strengthening of an artefact is a primary aim, the principle of irreversibility becomes secondary, and the application of epoxies can be approved. Irreversibility can be sometimes bypassed by coating the surface of a hole in wood with a reversible coating which enables the fill to be easily removed if necessary. The only problem that remains then is the proper adhesive strength between the coating and wood and between the coating and a fill [11-14,33,63,72].

Epoxy resins should not be used alone as fills for wooden objects because they can penetrate wooden tissue, thus irreversibly change the properties of wood (they are not flexible enough when they polymerise, making wood rigid, brittle, and prone to rupture). However, when combined with various fillers and additives that increase their viscosity, they can make a gap-filling paste ideal for filling voids, holes, checks, and splits of different origin in wooden objects. Epoxy-based masses adhere well to a wooden surface and are relatively durable and long-lasting, which makes them a good choice for external applications. They are easy to work with (sanding, carving, etc.), leaving a nice finished surface; they can also be coloured by adding pigments to resins or painting the surface of an already cured mass $[11,13,16,61,76,77]$. Unfortunately, they are not free from drawbacks. First of all, even when mixed with fillers (e.g., microballoons), they can still have high compression modulus. Under humid conditions, the surrounding wood can be stressed because it cannot expand while absorbing moisture, which may result in its warping or crushing. On the other hand, when such wood dries, tensile stress can cause check formation between the fill and wood [13,14]. Additionally, due to the different mechanical characteristics of microballoons and epoxy matrix, the stresses localised in various parts of the composite itself can cause cracks and voids in the fill [51]. Other concerns are the previously mentioned irreversibility, yellowing when exposed to heat or light (important for art or historical artefacts where epoxies are visible on the surface), and the heat released during the curing process $[13,33,77]$. Nevertheless, epoxy-based masses have been applied frequently for gap-filling in wooden artefacts exposed outdoors, and, in some cases (e.g., in applications where wooden artefact remains in a moderately stable relative humidity or when wood does not undergo significant dimensional changes upon changes in moisture conditions), they can be the best choice $[13,14,77,78]$.

\section{- Polyurethanes}

Polyurethanes are synthetic resins produced via polyaddition reaction of dialcohols or polyols and polyisocyanates. Depending on the chemical composition, both thermosetting plastics and elastomers are available with different properties. Therefore, they can be used in a wide range of industrial applications. Generally, they have medium viscosity, which makes them easy to mix and process, but also to cast and shape. They can be combined with various additives, including inhibitors, pigments or fillers, to give them properties required for specific applications. They have a short curing time and do not shrink much upon curing; however, their adhesive properties are not as good as those of epoxy resins [55,79-83].

Polyurethane resins can be used to produce polyurethane foams, which are commonly used as insulating materials in construction. In accordance with their mechanical characteristics, particularly their rigidity, stiffness, and compressive and tensile properties, they can be categorised as flexible, semi-rigid or rigid foams [82,84]. Their good dimensional stability, high durability, low weight, low thermic coefficient, good moisture and compression resistance, and easy workability make them also suitable for filling gaps in wooden artefacts. Polyurethane foams adhere well to wood and are resistant to high temperatures, UV radiation, and chemicals. However, their moisture properties are not compatible with wood. They should be applied layer by layer to the dry wood surface to limit temperature rise and ensure the proper foaming process. Cured foams are easily workable with all tools 
typically used for wood and can be painted. They can also be mechanically removed from an object when necessary $[84,85]$.

- Vinyl resins

The term "vinyl resin" refers to different compounds, usually vinyl acetate, vinyl chloride, vinyl ether, vinyl butyral or copolymer blends of these. They can be used in dispersions, emulsions, and solutions and also mixed with different additives (e.g., pigments) to tailor their properties to specific applications. They polymerise easily at ambient or elevated temperatures, and once cured, they are flexible and resistant to water and various chemicals. They adhere well to different surfaces and therefore are commonly employed as adhesives and coatings for various purposes [73,86].

Vinyl resins have found application as consolidants and fillers in wood conservation since the early 1950s. Some examples include a mixture of polyvinyl acetate with sawdust and gypsum applied for filling cracks and holes made by wood-destroying insects, or a blend of polyvinyl butyral, glass microballoons, and pigments applied for filling loses in ancient dry wooden furniture [31,33]. There are also different commercial ready-mixed vinyl filling masses intended for patching plaster or wallboard in the construction industry, which can be adapted for wood conservation. These materials are flexible, have good working properties, and great adhesion to wood. However, they are irreversible, susceptible to UV and heat ageing (they become yellow and brittle), and may be swelled by water, thus damaging paints or gildings and swelling the adjacent wood layers [33]. They may also shrink significantly upon curing and become much harder than low-density wood. All these make them less desirable as gap-fillers $[15,30,76]$.

- $\quad$ Silicone resins

Owing to exceptionally stable silicon-carbon and silicon-oxygen bonds, semi-organic silicone resins are particularly resistant to oxidation and thermal decomposition. Depending on the type of functional groups attached to the silicon atom, various polymers with different properties can be obtained and further modified via their reactive groups (alkyd, polyester, acrylic, and epoxy) to enhance their durability. They have high thermo-chemical stability and are resistant to external factors (humidity, UV radiation). These versatile materials are applied in almost all industry branches, as well as in art conservation [73,87-89].

Among silicon resins, particularly RTV (room-temperature-vulcanising silicone) silicones are suitable for filling losses in wooden objects. These dimethyl siloxanes are commonly available as proprietary formulations in most hardware stores. They are easy to apply, water-resistant, with long-term flexibility, and relatively stable when used outdoors. They do not penetrate wood tissue and can be easily removed by pulling them out of the voids. Their compression modulus is lower than that of most wood, and they can form a perfect, inert, durable, and elastic fill. However, they have poor working and finishing properties. To improve these, they can be blended with various additives, including pigments and fillers. The addition of fillers (e.g., powdered fibreglass or glass microballoons) increases their viscosity. This provides the surface with enough roughness to enable its finishing (sanding, carving, etc.) and painting with acrylic paints [13,16,30,63].

\section{Summary}

To summarise the information mentioned above, Table 1 presents the most important advantages and disadvantages of individual compounds of different filling materials in the context of gap-filling in wooden objects exhibited in the open air. 
Table 1. A summary of advantages and disadvantages of different materials for filling gaps in wooden artefacts exposed outdoors. Some examples of their application in conservation practice are given in parentheses.

\begin{tabular}{|c|c|c|}
\hline $\begin{array}{c}\text { Filling Material/Example of Its } \\
\text { Application in Conservation Practice }\end{array}$ & Advantages & Drawbacks \\
\hline \multicolumn{3}{|c|}{ Fillers } \\
\hline $\begin{array}{l}\text { wooden fills } \\
\text { (Chik Kwai Study Hall in Hong Kong } \\
\text { [32], The Castle of Racconigi [90], } \\
\text { wooden elements in Royal Palace in } \\
\text { Wilanów [91], wooden monument in the } \\
\text { World War II cemetery in Radomlje [78]) }\end{array}$ & $\begin{array}{l}\text { compatible with the wood of the same } \\
\text { age and species }\end{array}$ & $\begin{array}{l}\text { different response on moisture than } \\
\text { historic wooden tissue if inappropriately } \\
\text { chosen, needs to be precisely shaped to } \\
\text { ensure proper joint, difficult to match the } \\
\text { grain pattern }\end{array}$ \\
\hline $\begin{array}{l}\text { sawdust, wood shavings } \\
\text { (Chik Kwai Study Hall in Hong Kong } \\
\text { [32], wooden elements in Royal Palace in } \\
\text { Wilanów [91], wooden monument in the } \\
\text { World War II cemetery in Radomlie [78]) }\end{array}$ & $\begin{array}{c}\text { compatible with wood, easily available, } \\
\text { cheap, enhance mechanical performance } \\
\text { and workability of moldable } \\
\text { filling masses }\end{array}$ & $\begin{array}{l}\text { hygroscopic, appropriate for nonaqueous } \\
\text { binders (due to high swelling and } \\
\text { shrinkage of fragmented wood in contact } \\
\text { with water) }\end{array}$ \\
\hline cellulose & $\begin{array}{l}\text { non-toxic, easily applicable, compatible } \\
\text { with wood, thermo-chemically stable, } \\
\text { resistant to swelling in water, low density, } \\
\text { high viscosity and specific strength }\end{array}$ & - \\
\hline plaster and cement & $\begin{array}{l}\text { non-toxic, readily available } \\
\text { easily applicable, forms easy } \\
\text { workable pastes }\end{array}$ & $\begin{array}{l}\text { lime plaster shrinks and cracks during } \\
\text { drying; gypsum plaster expands upon } \\
\text { drying and thus can destroy the } \\
\text { surrounding wooden tissue; not suitable } \\
\text { for degraded wood and under } \\
\text { changeable moisture conditions }\end{array}$ \\
\hline $\begin{array}{c}\text { microballoons } \\
\text { (Totem pole from Canadian Museum of } \\
\text { Civilization [11]) }\end{array}$ & $\begin{array}{l}\text { non-toxic, low density, light weight, form } \\
\text { easily workable pastes, can be reversible, } \\
\text { reduce shrinkage during drying, improve } \\
\text { smoothness and mechanical performance } \\
\text { of filling masses, easily paintable, easily } \\
\text { mixed with various resins }\end{array}$ & 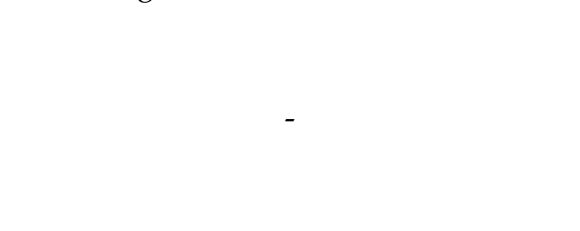 \\
\hline
\end{tabular}

Adhesives (Binders)

animal glues

waxes, oils

and natural resins

cellulose ethers and esters

acrylic resins

(wooden gateway from the historical centre of Brasov [56])

epoxy resins

(Totem pole from Canadian Museum of Civilization [11], Chik Kwai Study Hall in

Hong Kong [32], the wooden monument in the World War II cemetery in

Radomlje [78])

polyurethanes

(Ionic capitals from Mount Pleasant, a historic house in Fairmount Park, Philadelphia [16]) natural, non-toxic, completely reversible, excellent adhesion to the wood surface, do not stain wood

non-toxic, chemically stable, resistant to moisture and water, reversible, do not change colour upon ageing compatible with wood, response to moisture fluctuations similar to wood, good adhesion

flexible, high photo-thermal stability, good adhesion and mechanical properties, inert, reversible

easy to be carved, sanded or finishing after setting, durable, easily workable, resistant to weathering, good mechanical properties

easy to mix, process, cast, and shape, dimensionally stable upon drying, resistant to high temperatures, UV radiation and chemicals, durable, good moisture and compression resistance prone to biodegradation, extremely hygroscopic, very sensitive to moisture and temperature fluctuations (swelling and shrinkage)

vulnerable to dust accumulation, poor mechanical resistance, low bond strength, not resistant to heat

prone to shrink upon drying, become

brittle over time, poor penetration into wood

prone to biodegradation in the long term, UV radiation, and mechanical damage

irreversible after curing, easily penetrate wood tissue-not appropriate to use alone since they change wood properties

insoluble in solvents once cured, moisture properties different from wood 
Table 1. Cont.

\begin{tabular}{|c|c|c|}
\hline $\begin{array}{l}\text { Filling Material/Example of Its } \\
\text { Application in Conservation Practice }\end{array}$ & Advantages & Drawbacks \\
\hline $\begin{array}{l}\text { vinyl resins } \\
\text { (adornments in towers of Royal Palace at } \\
\text { Wilanów [92], wooden elements in Royal } \\
\text { Palace in Wilanów [91]) }\end{array}$ & $\begin{array}{l}\text { quite soft, flexible, easily workable, } \\
\text { resistant to water and chemicals, } \\
\text { good adhesion }\end{array}$ & $\begin{array}{l}\text { in mixtures with different compounds } \\
\text { can be irreversible, susceptible to UV and } \\
\text { heat ageing, shrink upon drying, may be } \\
\text { swelled by water and destroy gildings } \\
\text { and paints }\end{array}$ \\
\hline $\begin{array}{c}\text { silicone resins (wooden doors attributed } \\
\text { to the Spanish Colonial period from a } \\
\text { historic farmstead south of San } \\
\text { Antonio [63]) }\end{array}$ & $\begin{array}{l}\text { high thermo-chemical stability, resistance } \\
\text { to external factors, elastic, do not } \\
\text { penetrate the wood fibres, inert after } \\
\text { curing, compression modulus lower than } \\
\text { wood, resistant to water, easily reversed } \\
\text { by mechanically pulling them out of the } \\
\text { gap, durable (at least } 10 \text { years when } \\
\text { used outdoors) }\end{array}$ & $\begin{array}{l}\text { poor working properties, low } \\
\text { compatibility with paint, may penetrate } \\
\text { wood before curing }\end{array}$ \\
\hline
\end{tabular}

\section{Conclusions}

The presented survey leads to the conclusion that although the materials applied for filling losses in wooden artefacts exposed outdoors are highly diverse, none of them fully comply with all conditions required for outdoor application in wood or meet all requirements of conservation ethics, perhaps because none of them was intended for such a purpose. The most common problem of filling materials concerns their compatibility with wood, mainly susceptibility to moisture and the relating dimensional changes, as well as mechanical properties. Excessive shrinkage or swelling of fills in response to humidity fluctuations, different from wood behaviour may threaten the integrity of wooden artefacts. The same relates to differences in flexibility, compression or tensile strength. Another serious drawback involves poor adhesion of fills to the wood surface or insufficient cohesion of the fill itself; they can lead to gap formation between wood and filling mass or within a fill, further microbial infestations due to the presence of water collected in new cracks and, as a consequence, degradation of the wooden object. Susceptibility to weather conditions and biodegradation, causing changes in wood colour or damaging paints and gildings on the wood surface as well as irreversibility, complete the list of shortcomings. Therefore, there is a constant need to develop new, more effective gap-fillers to properly protect priceless historical wooden objects for future generations.

It can be concluded that among the most promising materials are blends and composites made up of various substances, particularly natural compounds compatible with wood. Depending on the composition and the ratios of individual components, the properties of such materials could be potentially adjusted to the needs and requirements of specific applications. Broad research has been conducted recently on composites based on both natural and synthetic components for various purposes that proves the possibility of developing materials with desired characteristics [79-81,83,93-96]. However, as pointed out by Fulcher [18], it should be remembered that such filling composites, " ... should be considered as a system, and its properties are not a sum of the properties of its components, because individual ingredients-a bulking agent, an adhesive and a solvent-affect each other, modifying the resulting material and its reactions to the surrounding environment".

Having efficient, safe, and verified conservation materials and methods is essential to preserve our cultural heritage, but, even if there are some good filling materials, there is still not enough scientific data on their long-term behaviour and durability. Therefore, close cooperation between scientists and conservators is necessary to understand both the needs of cultural heritage artefacts and the properties of materials proposed for their conservation and make all the process being in line with conservation ethics, because "Conservation practice seeks to understand and preserve tangible cultural property, whereas conservation ethics seek to understand and preserve intangible cultural property" [5]. 
Author Contributions: Conceptualisation, M.B. and P.K.; writing—original draft preparation, M.B., P.K. and G.A.O.; writing-review and editing, P.K., M.B. and G.A.O.; visualisation, P.K. and M.B.; supervision, M.B. All authors have read and agreed to the published version of the manuscript.

Funding: This research received no external funding.

Institutional Review Board Statement: Not applicable.

Informed Consent Statement: Not applicable.

Conflicts of Interest: The authors declare no conflict of interest. The funders had no role in the design of the study; in the collection, analyses, or interpretation of data; in the writing of the manuscript, or in the decision to publish the results.

\section{References}

1. Ali, Z.M.; Zawawi, R. Contributions of Open Air Museums In Preserving Heritage Buildings: Study of Open-Air Museums in South East England. JDBE 2010, 7. Available online: https://ejournal.um.edu.my/index.php/jdbe/article/view/5298 (accessed on 10 April 2021).

2. Paardekooper, R. The Value of an Archaeological Open-Air Museum Is in Its Use: Understanding Archaeological Open-Air Museums and Their Visitors; Sidestone Press: Leiden, The Netherlands, 2012.

3. Sevan, O. Open Air Museums as Ways of Preserving and Transmitting the Spirit of Place. In Proceedings of the 16th ICOMOS General Assembly and International Symposium: 'Finding the Spirit of Place-Between the Tangible and the Intangible', Quebec, QC, Canada, 29 September-4 October 2008.

4. Hurt, R.D. Agricultural Museums: A New Frontier for the Social Sciences. Hist. Teach. 1978, 11, 367-375. [CrossRef]

5. Rivers, S. Conservation of Japanese Lacquer in Western Collections-Conserving Meaning and Substance. In Proceedings of the Preprints of the 14th Triennial Meeting of the ICOM Committee for Conservation, The Hague, The Netherlands, 12-16 September 2005; James \& James: London, UK, 2005; pp. 1083-1086.

6. Schmidt, O. Wood and Tree Fungi: Biology, Damage, Protection, and Use; Springer Science \& Business Media: Berlin/Heidelberg, Germany, 2006.

7. Tolvaj, L.; Popescu, C.-M.; Molnar, Z.; Preklet, E. Effects of Air Relative Humidity and Temperature on Photodegradation Processes in Beech and Spruce Wood. BioResources 2016, 11, 296-305. [CrossRef]

8. Witomski, P. Konserwacja Zachowawcza a Trwa \lość Budowli Drewnianych. Bud. I Archit. 2015, 14, 157-164. [CrossRef]

9. Wermuth, J.A. Simple and Integrated Consolidation Systems for Degraded Wood. In Archaeological Wood; Advances in Chemistry; American Chemical Society: Washington, DC, USA, 1989; Volume 225, pp. 301-359. ISBN 978-0-8412-1623-5.

10. Podmaniczky, M.S. Structural Fillsfor Large Wood Objects: Contrasting and Complementary Approaches. JAIC 1998, 37, 111-116. [CrossRef]

11. Barclay, R.; Mathias, C. An Epoxy/Microballoon Mixture for Gap Filling in Wooden Objects. JAIC 1989, 28, 31-42. [CrossRef]

12. Phillips, M.W.; Selwyn, J.E. Epoxies for Wood Repairs in Historic Buildings; Office of Archeology and Historic Preservation, Heritage Conservation and Recreation Service, US Department of the Interior, Technical Preservation Services Division: Washington DC, USA, 1978.

13. Grattan, D.W.; Barclay, R.L. A Study of Gap-Fillers for Wooden Objects. Stud. Conserv. 1988, 33, 71-86. [CrossRef]

14. Cleary, R. Considering the Use of Epoxies in the Repair of Historic Structural Timber. Master's Thesis, University of Pennsylvania, Philadelphia, PA, USA, 2014.

15. Craft, M.L.; Solz, J.A. Commercial Vinyl and Acrylic Fill Materials. JAIC 1998, 37, 23-34. [CrossRef]

16. Deurenberg-Wilkinson, R.M. Choosing an Adhesive for Exterior Woodwork Through Mechanical Testing. JAIC 2015, 54, 74-90. [CrossRef]

17. Thornton, J. A Brief History and Review of the Early Practice and Materials of Gap-Filling Inthe West. JAIC 1998, 37, 3-22. [CrossRef]

18. Fulcher, K. An Investigation of the Use of Cellulose-Based Materials to Gap-Fill Wooden Objects. Stud. Conserv. 2017, 62, 210-222. [CrossRef]

19. Fulcher, K.E. Survey on Material Used to Fill Wooden Objects during Conservation. J Open Archaeol Data 2014, 3. [CrossRef]

20. Cataldi, A.; Dorigato, A.; Deflorian, F.; Pegoretti, A. Effect of the Water Sorption on the Mechanical Response of Microcrystalline Cellulose-Based Composites for Art Protection and Restoration. J. Appl. Polym. Sci. 2014, 131. [CrossRef]

21. Cataldi, A.; Deflorian, F.; Pegoretti, A. Microcrystalline Cellulose Filled Composites for Wooden Artwork Consolidation: Application and Physic-Mechanical Characterization. Mater. Des. 2015, 83, 611-619. [CrossRef]

22. Cataldi, A.; Dorigato, A.; Deflorian, F.; Pegoretti, A. Thermo-Mechanical Properties of Innovative Microcrystalline Cellulose Filled Composites for Art Protection and Restoration. J. Mater. Sci. 2014, 49, 2035-2044. [CrossRef]

23. Kryg, P.; Mazela, B.; Broda, M. Dimensional Stability and Moisture Properties of Gap-Fillers Based on Wood Powder and Glass Microballoons. Stud. Conserv. 2020, 65, 142-151. [CrossRef] 
24. Infurna, G.; Cavallaro, G.; Lazzara, G.; Milioto, S.; Dintcheva, N.T. Bionanocomposite Films Containing Halloysite Nanotubes and Natural Antioxidants with Enhanced Performance and Durability as Promising Materials for Cultural Heritage Protection. Polymers 2020, 12, 1973. [CrossRef] [PubMed]

25. Cavallaro, G.; Milioto, S.; Lazzara, G. Halloysite Nanotubes: Interfacial Properties and Applications in Cultural Heritage. Langmuir 2020, 36, 3677-3689. [CrossRef]

26. Broda, M. Natural Compounds for Wood Protection against Fungi-A Review. Molecules 2020, 25, 3538. [CrossRef]

27. Bettina, G.F.; Giambra, B.; Cavallaro, G.; Lazzara, G.; Megna, B.; Fakhrullin, R.; Akhatova, F.; Fakhrullin, R. Restoration of a XVII Century's Predella Reliquary: From Physico-Chemical Characterization to the Conservation Process. Forests 2021, 12, 345. [CrossRef]

28. Fulcher, K. The Diverse Use of AJK Dough in Conservation. J. Inst. Conserv. 2014, 37, 32-42. [CrossRef]

29. Abdallah, M.; Kamal, H.M.; Abdrabou, A. Investigation, Preservation and Restoration Processes of an Ancient Egyptian Wooden Offering Table. IJCS 2016, 7, 1047-1064.

30. Williams, D.C. Some Experiences with Flexible Gap-Filling Adhesives for the Conservation of Wood Objects. In Proceedings of the Facing the Challenges of Panel Paintings Conservation: Trends, Treatments, and Training, Los Angeles, CA, USA, 17-18 May 2009.

31. Unger, A.; Schniewind, A.; Unger, W. Conservation of Wood Artifacts: A Handbook; Springer Science \& Business Media: Berlin/Heidelberg, Germany, 2001.

32. Leung, E.S.; Yeung, E.S.; Chan, S.W. Strike a Balance-Repair or Replace? Adv. Mater. Res. 2010, 133, 997-1002.

33. Young, C.; Ackroyd, P.; Hibberd, R.; Gritt, S. The Mechanical Behaviour of Adhesives and Gap Fillers for Re-Joining Panel Paintings. Natl. Gallery Tech. Bull. 2002, 23, 83-96.

34. Huuhilo, T.; Martikka, O.; Butylina, S.; Kärki, T. Mineral Fillers for Wood-Plastic Composites. Wood Mater. Sci. Eng. 2010, 5, 34-40. [CrossRef]

35. Antonelli, F.; Galotta, G.; Sidoti, G.; Zikeli, F.; Nisi, R.; Petriaggi, B.D.; Romagnoli, M. Cellulose and Lignin Nano-Scale Consolidants for Waterlogged Archaeological Wood. Front. Chem. 2020, 8. [CrossRef] [PubMed]

36. Hamed, S.A.A.K.M.; Hassan, M.L. A New Mixture of Hydroxypropyl Cellulose and Nanocellulose for Wood Consolidation. J Cult. Herit. 2019, 35, 140-144. [CrossRef]

37. Fierascu, R.C.; Doni, M.; Fierascu, I. Selected Aspects Regarding the Restoration/Conservation of Traditional Wood and Masonry Building Materials: A Short Overview of the Last Decade Findings. Appl. Sci. 2020, 10, 1164. [CrossRef]

38. Haldar, D.; Purkait, M.K. Micro and Nanocrystalline Cellulose Derivatives of Lignocellulosic Biomass: A Review on Synthesis, Applications and Advancements. Carbohydr. Polym. 2020, 250, 116937. [CrossRef]

39. Collazo-Bigliardi, S.; Ortega-Toro, R.; Boix, A.C. Isolation and Characterisation of Microcrystalline Cellulose and Cellulose Nanocrystals from Coffee Husk and Comparative Study with Rice Husk. Carbohydr. Polym. 2018, 191, 205-215. [CrossRef]

40. Katakojwala, R.; Mohan, S.V. Microcrystalline Cellulose Production from Sugarcane Bagasse: Sustainable Process Development and Life Cycle Assessment. J. Clean. Prod. 2020, 249, 119342. [CrossRef]

41. Rasheed, M.; Jawaid, M.; Karim, Z.; Abdullah, L.C. Morphological, Physiochemical and Thermal Properties of Microcrystalline Cellulose (MCC) Extracted from Bamboo Fiber. Molecules 2020, 25, 2824. [CrossRef] [PubMed]

42. El Hadidi, N.; Abdel-Monem, H.; Mohamed, M.; Hashem, G. Retreatment and Conservation of a Wooden Panel Previously Treated with Bees Wax. Adv. Res. Conserv. Sci. 2020, 1, 48-65. [CrossRef]

43. Artal-Isbrand, P. So Delicate yet so Strong and Versatile-the Use of Paper in Objects Conservation. JAIC 2018, 57, 112-126. [CrossRef]

44. Chen, H.; Nair, S.S.; Chauhan, P.; Yan, N. Lignin Containing Cellulose Nanofibril Application in PMDI Wood Adhesives for Drastically Improved Gap-Filling Properties with Robust Bondline Interfaces. Chem. Eng. J. 2019, 360, 393-401. [CrossRef]

45. Asgari, A.; Hemmasi, A.; Bazyar, B.; Talaeipour, M.; Nourbakhsh, A. Inspecting the Properties of Polypropylene/ Poplar Wood Flour Composites with Microcrystalline Cellulose and Starch Powder Addition. BioResources 2020, 15, 4188-4204.

46. Karakus, K.; Atar, İ.; Başboğa, İ.H.; Bozkurt, F.; Mengeloğlu, F. Wood Ash and Microcrystalline Cellulose (MCC) Filled Unsaturated Polyester Composites. Kast. Univ. J. For. Fac. 2017, 17, 282-289. [CrossRef]

47. Hatchfield, P. Note on a Fill Material for Water Sensitive Objects. JAIC 1986, 25, 93-96. [CrossRef]

48. Iaccarino Idelson, A.; Pannuzi, S.; Brunetto, A.; Galanti, G.; Giovannone, C.; Massa, V.; Serino, C.; Vischetti, F. Use of 3D technologies within the conservation of the ancientwindows of the basilica of s. Sabina in rome. Construction ofexhibition stands in carbon composite on a milled structure. Int. Arch. Photogramm. Remote Sens. Spat. Inf. Sci. 2017, XLII-5/W1, 593-598. [CrossRef]

49. Nabil, E. Scientific Methods for the Treatment of Ibis Mummy's Wooden Coffin. Egypt. J. Archaeol. Restor. Stud. 2020, 10, 9-21. [CrossRef]

50. Carlisle, K.B.; Chawla, K.K.; Gladysz, G.M.; Koopman, M. Structure and Mechanical Properties of Micro and Macro Balloons: An Overview of Test Techniques. J. Mater. Sci. 2006, 41, 3961-3972. [CrossRef]

51. Huang, R.; Li, P. Elastic Behaviour and Failure Mechanism in Epoxy Syntactic Foams: The Effect of Glass Microballoon Volume Fractions. Compos. Part B Eng. 2015, 78, 401-408. [CrossRef]

52. Hsu, H.-H.; Sully, D. Fusing and Refreshing the Memory: Conserving a Chinese Lacquered Buddha Sculpture in London. Stud. Conserv. 2016, 61, 124-130. [CrossRef]

53. Nakhla, S.M. A Comparative Study of Resins for the Consolidation of Wooden Objects. Stud. Conserv. 1986, 31, 38-44. [CrossRef] 
54. Schellmann, N. Consolidation of Stressed and Lifting Decorative Coatings on Wood. The Effect on Consolidant Choice on the Structural Integrity of Multilayered East Asian Lacquer Coatings with Gesso-Like Foundation Layers. Ph.D. Thesis, Hochschule der Bildenden Künste Dresden, Dresden, Germany, 2012.

55. Rivers, S.; Umney, N. Conservation of Furniture; Routledge: Oxfordshire, UK, 2007.

56. Tuduce-Traistaru, A.-A.; Campean, M.; Timar, M.C. Compatibility Indicators in Developing Consolidation Materials with Nanoparticle Insertions for Old Wooden Objects. Int. J. Conserv. Sci. 2010, 1, 219-226.

57. Schellmann, N.C. Animal Glues: A Review of Their Key Properties Relevant to Conservation. Stud. Conserv. 2007, 52, 55-66. [CrossRef]

58. McGlinchey, C. Polymers in Conservation. Encycl. Archaeol. Sci. 2018, 1-3. [CrossRef]

59. Jeszeová, L.; Bauerová-Hlinková, V.; Baráth, P.; Puškárová, A.; Bučková, M.; Kraková, L.; Pangallo, D. Biochemical and Proteomic Characterization of the Extracellular Enzymatic Preparate of Exiguobacterium Undae, Suitable for Efficient Animal Glue Removal. Appl. Microbiol. Biotechnol. 2018, 102, 6525-6536. [CrossRef]

60. Webb, M. Methods and Materials for Filling Losses on Lacquer Objects. JAIC 1998, 37, 117-133. [CrossRef]

61. Szczepińska, K. Historycznie Stosowane Impregnaty Do Wzmacniania Zniszczonego Drewna Polichromowanego-Próba Przeglądu. Część II: Impregnaty Syntetyczne. Acta Univ. Nicolai Copernic. Zabytkozn. I Konserw. 2015, 469-508. [CrossRef]

62. Szczepińska, K. Historycznie stosowane impregnaty do wzmacniania zniszczonego drewna polichromowanego-próba przeglądu. Część I: Impregnaty naturalne. Acta Univ. Nicolai Copernic. 2014, 569. [CrossRef]

63. Storch, P.S. Fills for Bridging Structural Gaps in Wooden Objects. J. Am. Inst. Conserv. 1994, 33, 71-75. [CrossRef]

64. Majewicz, T.G.; Erazo-Majewicz, P.E.; Podlas, T.J. Cellulose Ethers. Encycl. Polym. Sci. Technol. 2002. [CrossRef]

65. Shaghaleh, H.; Xu, X.; Wang, S. Current Progress in Production of Biopolymeric Materials Based on Cellulose,. Cellulose Nanofibers, and Cellulose Derivatives. RSC Adv. 2018, 8, 825-842. [CrossRef]

66. Walsh, Z.; Janeček, E.-R.; Jones, M.; Scherman, O.A. Natural Polymers as Alternative Consolidants for the Preservation of Waterlogged Archaeological Wood. Stud. Conserv. 2017, 62, 173-183. [CrossRef]

67. Cavallaro, G.; Lazzara, G.; Milioto, S.; Parisi, F. Halloysite Nanotubes for Cleaning, Consolidation and Protection. Chem. Rec. 2018, 18, 940-949. [CrossRef] [PubMed]

68. Elston, M. Technology and Conservation of a Polychromed Wooden Sarcophagus. In Proceedings of the Conservation in Ancient Egyptian Collections, London, UK, 20-21 July 1995; pp. 13-21.

69. Gänsicke, S.; Hatchfield, P.; Hykin, A.; Svoboda, M.; Tsu, C.M.-A. The Ancient Egyptian Collection at the Museum of Fine Arts, Boston. Part 2, A Review of Former Treatments at the MFA and Their Consequences. JAIC 2003, 42, 193-236. [CrossRef]

70. Johnson, C.; Head, K.; Green, L. The Conservation of a Polychrome Egyptian Coffin. Stud. Conserv. 1995, 40, 73-81. [CrossRef]

71. Cappitelli, F.; Zanardini, E.; Sorlini, C. The Biodeterioration of Synthetic Resins Used in Conservation. Macromol. Biosci. 2004, 4, 399-406. [CrossRef]

72. Ellis, J.L.; Ball, A. Comparison of Two Wood Filler Types with Respect to Relative Shrinkage across Variations in Temperature, in Humidity and within Wood Species. Int. Wood Prod. J. 2011, 2, 115-119. [CrossRef]

73. Bentley, J. 2-Organic film formers. In Paint and Surface Coatings, 2nd ed.; Lambourne, R., Strivens, T.A., Eds.; Woodhead Publishing Series in Metals and Surface Engineering; Woodhead Publishing: Cambridge, UK, 1999; pp. 19-90. ISBN 978-1-85573-348-0.

74. Crisci, G.M.; La Russa, M.F.; Malagodi, M.; Ruffolo, S.A. Consolidating Properties of Regalrez 1126 and Paraloid B72 Applied to Wood. J. Cult. Herit. 2010, 11, 304-308. [CrossRef]

75. May, C. Epoxy Resins: Chemistry and Technology; Routledge: Oxfordshire, UK, 2018.

76. Fox, M. Searching for the Filler of My Dreams-An Odyssey in Gaps and Glues. J. Vertebr. Paleontol. 2001, 21, 51A. Available online: http:/ / preparation.paleo.amnh.org/assets/Fox-gapfillerpaper.pdf (accessed on 10 April 2021).

77. Ellis, L.; Heginbotham, A. An Evaluation of Four Barrier-Coating and Epoxy Combinations in the Structural Repair of Wooden Objects. J. Am. Inst. Conserv. 2004, 43, 23-37. [CrossRef]

78. Pamic, R.; Pohleven, F. Protection through Construction of a Wooden Monument in Radomlje (Slovenia). Drewno Prace Nauk. Doniesienia Komun. 2015, 58. [CrossRef]

79. Santamaria-Echart, A.; Fernandes, I.; Barreiro, F.; Corcuera, M.A.; Eceiza, A. Advances in Waterborne Polyurethane and Polyurethane-Urea Dispersions and Their Eco-Friendly Derivatives: A Review. Polymers 2021, 13, 409. [CrossRef]

80. Brzeska, J.; Tercjak, A.; Sikorska, W.; Mendrek, B.; Kowalczuk, M.; Rutkowska, M. Degradability of Polyurethanes and Their Blends with Polylactide, Chitosan and Starch. Polymers 2021, 13, 1202. [CrossRef]

81. Członka, S.; Kairytė, A.; Miedzińska, K.; Strąkowska, A.; Adamus-Włodarczyk, A. Mechanically Strong Polyurethane Composites Reinforced with Montmorillonite-Modified Sage Filler (Salvia officinalis L.). Int. J. Mol. Sci. 2021, 22, 3744. [CrossRef]

82. Randall, D.; Lee, S. The Polyurethanes Book; Wiley-Blackwell: Hoboken, NJ, USA, 2002.

83. Alinejad, M.; Henry, C.; Nikafshar, S.; Gondaliya, A.; Bagheri, S.; Chen, N.; Singh, S.K.; Hodge, D.B.; Nejad, M. Lignin-Based Polyurethanes: Opportunities for Bio-Based Foams, Elastomers, Coatings and Adhesives. Polymers 2019, 11, 1202. [CrossRef]

84. Xu, Z.; Tang, X.; Gu, A.; Fang, Z. Novel Preparation and Mechanical Properties of Rigid Polyurethane Foam/Organoclay Nanocomposites. J. Appl. Polym. Sci. 2007, 106, 439-447. [CrossRef]

85. Soldenhoff, B. Zastosowanie Sztywnych Pianek Poliuretanowych do Uzupełniania Ubytków Drewna w Obiektach Zabytkowych. Acta Univ. Nicolai Copernic. Nauk. Humanist. Spo/Lecz. Zabytkozn. I Konserw. 1979, 7, 145-153. 
86. Buchheit, R.G. 18-Corrosion Resistant Coatings and Paints. In Handbook of Environmental Degradation of Materials, 2nd ed.; Kutz, M., Ed.; William Andrew Publishing: Oxford, UK, 2012; pp. 539-568. ISBN 978-1-4377-3455-3.

87. Robeyns, C.; Picard, L.; Ganachaud, F. Synthesis, Characterization and Modification of Silicone Resins: An "Augmented Review". Prog. Org. Coat. 2018, 125, 287-315. [CrossRef]

88. Broda, M.; Dąbek, I.; Dutkiewicz, A.; Dutkiewicz, M.; Popescu, C.-M.; Mazela, B.; Maciejewski, H. Organosilicons of Different Molecular Size and Chemical Structure as Consolidants for Waterlogged Archaeological Wood-A New Reversible and Retreatable Method. Sci. Rep. 2020, 10, 1-13. [CrossRef]

89. Barclay, R.L.; Grattan, D.W. A Silicone Rubber/Microballoon Mixture for Gap Filling in Wooden Objects. In Proceedings of the ICOM Committee for Conservation: 8th Triennial Meeting, Sydney, Australia, 6-11 September 1987; Preprints. Volume 1, pp. 183-187.

90. Bertolini Cestari, C.; Marzi, T. Conservation of Historic Timber Roof Structures of Italian Architectural Heritage: Diagnosis, Assessment, and Intervention. Int. J. Arch. Herit. 2018, 12, 632-665. [CrossRef]

91. Czajnik, M.; Rudniewski, P.; Tworek, D. Niektóre Zagadnienia z Prac Nad Konserwacją Elementów Drewnianych. Ochrona Zabytków 1962, 33, 77-85.

92. Ważny, J. Badanie Wplywu Impregnacji Vinoflexem MP-400 Na Wlaściwości Techniczne Drewna Wystroju Rzeźbiarskiego Wież Palacu w Wilanowie. Ochrona Zabytków 1970, 23/2, 83-88. Available online: http:/ /yadda.icm.edu.pl/yadda/element/bwmeta1 .element.desklight-dd146a1e-5cc0-49c9-b7cc-f1fec13ec597 (accessed on 10 March 2021).

93. Sarraj, S.; Szymiczek, M.; Machoczek, T.; Mrówka, M. Evaluation of the Impact of Organic Fillers on Selected Properties of Organosilicon Polymer. Polymers 2021, 13, 1103. [CrossRef]

94. Réh, R.; Krišták, L.; Sedliačik, J.; Bekhta, P.; Božiková, M.; Kunecová, D.; Vozárová, V.; Tudor, E.M.; Antov, P.; Savov, V. Utilization of Birch Bark as an Eco-Friendly Filler in Urea-Formaldehyde Adhesives for Plywood Manufacturing. Polymers 2021, $13,511$. [CrossRef] [PubMed]

95. Hejna, A.; Barczewski, M.; Kosmela, P.; Mysiukiewicz, O.; Kuzmin, A. Coffee Silverskin as a Multifunctional Waste Filler for High-Density Polyethylene Green Composites. J. Compos. Sci. 2021, 5, 44. [CrossRef]

96. Bejenari, I.; Dinu, R.; Montes, S.; Volf, I.; Mija, A. Hydrothermal Carbon as Reactive Fillers to Produce Sustainable Biocomposites with Aromatic Bio-Based Epoxy Resins. Polymers 2021, 13, 240. [CrossRef] [PubMed] 